INDONESIAN JOURNAL OF NURSING AND MIDWIFERY

\title{
Premenstrual Dysphoric Disorder Causes Discomfort And Interfere Adolescent's Social
} Relationship

\author{
Dewi Marfuah \\ STIKEP PPNI Jawa Barat \\ Ahmad IV street, No. 32, Bandung, West Java, Indonesia \\ Email: dewi.marfuah@yahoo.com
}

\begin{abstract}
Abstrak
Menstruasi adalah keluarnya darah dari rahim melalui vagina yang terjadi setiap bulan. Premenstrual syndrome (PMS) adalah salah satu gangguan menstruasi dan masalah kesehatan pada wanita reproduksi dengan prevalensi sekitar 20-40\%. Sementara, Premenstrual Disphoric Disorder (PMDD) adalah bentuk parah dari PMS dengan prevalensi sekitar 3-8\%. Prevalensi PMS dan PMDD meningkat di Pasca daerah bencana sekitar $47,3 \%$ dan 41,8\%. Namun, tidak ada penelitian yang bertujuan untuk menggambarkan tentang pengalaman kehidupan remaja dengan sindrom PMDD di pasca bencana. Penelitian ini bertujuan untuk menggambarkan pengalaman remaja yang mengalami gejala PMDD. Penelitian ini menggunakan penelitian kualitatif dengan pendekatan fenomenologis. Jumlah peserta adalah enam siswa perempuan dari SMK Negeri 1 Cangkringan, Yogyakarta, Indonesia yang memenuhi PMDD berdasarkan Manual Diagnostik dan Statistik Gangguan Mental DSM-IV. Wawancara mendalam dengan wawancara tidak terstruktur dan menggunakan metode Colaizzi untuk analisis data. Demikian untuk kepercayaan dengan triangulasi sumber data untuk guru dan teman sekelasnya. Hasil menemukan empat tema utama yang menggambarkan pengalaman remaja dengan sindrom PMDD terbentuk: gejala dianggap sebagai perubahan yang mempengaruhi psikologis, perilaku dan fisik; gejalanya sesekali sepanjang siklus menstruasi; faktor lingkungan dan hormonal berperan dalam timbulnya gejala; dan gejala menyebabkan ketidaknyamanan dan mengganggu hubungan sosial remaja. Pengalaman remaja dengan gejala PMDD pascabencana sama seperti kondisi normal yang menyebabkan ketidaknyamanan yang mengganggu hubungan sosial remaja. Perawat dan personel media lainnya di lembaga perawatan kesehatan diharapkan untuk lebih aktif berpartisipasi untuk menyediakan berbagai pendidikan kesehatan reproduksi terkait dan memberikan intervensi untuk mengurangi PMDD dalam rangka meningkatkan Kualitas Hidup Perempuan.
\end{abstract}

Kata kunci : Remaja, Erupsi Merapi, Gangguan Premenstrual Premenstrual.

\begin{abstract}
Menstruation is the discharge of blood from the uterus through the vagina which happens monthly. Premenstrual syndrome (PMS) is one of menstrual disorder and a health problem in reproductive women with a prevalence about 20-40\%. While Premenstrual Dysphoric Disorder (PMDD) is a severe form of PMS with prevalence about 3-8\%. Prevalence of PMS and PMDD increased in Pasca of disaster area about 47,3\% and $41,8 \%$. However, no researches aim to describe life experience of adolescence with PMDD's syndromes in pasca of disaster area. This study aimed to describe adolescents's experience who experiencing symptoms of PMDD. This study used a qualitative study with phenomenological approach. Number of participants were six female students of SMK Negeri 1 Cangkringan, Yogyakarta, Indonesia that meet PMDD based on the Diagnostic
\end{abstract}


and Statistic Manual of Mental Disorders DSM-IV. In-depth interviews with a unstructured interview and using Colaizzi method for analysis data. Thus for trustworthiness with data source triangulation to their teachers and classmates. The results found four main themes describing the experience of adolescence with PMDD's syndromes were formed: symptoms perceived as a change that affects the psychological, behavioral and physical; symptoms are intermittent along the menstrual cycle; environmental and hormonal factors play a role in the onset of symptoms; and symptoms cause discomfort and interfere social relationships of adolescents. Adolescents's experience with symptoms of PMDD postdisaster as like as the normal condition that cause discomfort that interferes adolescent's social relationship. Nurses and other media personnel in the health care institution is expected to more actively participate to provide a wide range of related reproductive health education and giving intervention to reduce PMDD in order to increasing Women's Quality of Life.

Keywords: Adolescent, Merapi eruption, Premenstrual dysphoric disorder.

Article info:

Article submitted on September 14, 2018

Articles revised on October 16, 2018

Articles received on November 12, 2018

DOI: $h$ ttp://dx.doi.org/10.21927/jnki.2018.6(3).219-225

\section{INTRODUCTIONS}

Menstruation is bleeding from the uterus through the vagina that occurs every month(1). Menstrual disorders are problems that occur in the menstrual cycle. Menstrual disorders occur due to many factors, including due to abnormal anatomical, physiological imbalance, and lifestyle(2).

The prevalence of PMS (Premenstrual syndromes) of $18.5 \%$ and PMDD (premenstrual dysphoric disorder) of $8.4 \%$ in adolescents in Kobe, Japan(3). Premenstrual Dysphoric Disorder (PMDD) is a severe form of PMS. The American College of Obstetricians and Gynecologists (ACOG) diagnose of PMDD based prospective symptom diary indicated for about 2 months, which symptoms include physical symptoms and physiology and behavior(4).

Women with premenstrual disorders have a quality of life (Health-related quality of life) were low and found that severe mood disorders cycles during the luteal phase of the menstrual cycle can potentially degrade the quality of life(5).

Based on information obtained from the observation of researchers, SMK Negeri 1
Cangkringan is one school that is located closest to the peak of Merapi is located in $10 \mathrm{~km}$ zone. In 2010, SMK Negeri 1 Cangkringan affected by the eruption of Mount Merapi is severe enough to destroy the buildings. And found in 2012 as much as $47.3 \%$ prevalence of PMS and PMDD as much as $41.8 \%(3)$.

Post - Traumatic Stress Disorder (PTSD) is a psychological disorder that appears after a disaster occurs and more dangerous than the stress experienced at the time of the disaster(6). Stress experienced at the time of the disaster will generally be easier to administer than the treatment of PTSD(7). PTSD will lead to the victim suffered severe stress disorder, sleep disorders, withdrawal from social and anxiety are very high. PTSD can impact the behavior of extreme, debilitating of motivation and difficult to intervention(8).

In Outline, the incidence of traumatic stress in adolescents and prolonged stress which is one of the psychological factors that cause the symptoms of the premenstrual dysphoric disorder (PMDD) (9). Stress has a strong relationship with 
PMDD but not with PMS (10). Stressful life as interference in the relationship with the partner, interference with work and social activities and the presence of symptoms of major depression was also shown to increase the incidence of PMDD(11).

Based on the above, researchers interested in studying the phenomena that occur in adolescents who suffer from PMDD in SMK Negeri 1 Cangkringan. The purpose of this study is to describe the experience of adolescents who experience symptoms of the premenstrual dysphoric disorder (PMDD) in SMK Negeri 1 Cangkringan.

\section{MATERIALS AND METHODE}

The design of this study is qualitative research with a phenomenological approach. The phenomenological method used in this research is descriptive phenomenology with Colaizzi Technique analysis. The student population at SMK Negeri 1 Cangkringan was 237 students. Found there are 19 female students or $8 \%$ of the 237 girls and samples taken for in-depth interviews were 6 girls having reached saturation data. The method used is purposive sampling with inclusion criteria were; have regular menstrual cycles during the past 3 months (21-35 days), meet the diagnostic criteria for PMDD with DSM - IV, No experiencing Post Traumatic Stress Disorder (PTSD), no experiencing menstrual disorders other than PMDD, such as premenstrual syndrome (PMS), amenorrhoea, Oligomenorrhea, and polymenorrhea, no consumption of illegal drugs or alcohol during the past 2 years, and also willing to be a participant.

The primary data collection phase includes the division of the identity of participants, participant consent form, a questionnaire for the diagnosis of PMDD and instruments for measuring PTSD. As for the collection of qualitative data on adolescent experience with PMDD conducted by the researcher through in- depth interviews. The measuring instrument used for data collection in this study, among others; Criteria for diagnosis of PMS / PMDD according to the American College of Obstetricians and Gynecologies (ACOG) and the Diagnostic and Statistic Manual of Mental Disorders (DSM - IV) and the Impact of Event Scale-Revised (IES - R) were used to measure Post Traumatic Syndrome Disorder (PTSD). This questionnaire consists of 22 questions covering two symptoms of PTSD are flashbacks of events and avoidance of stimuli to measure the perceived distress last seven days associated with the traumatic event or disaster ever experience.

\section{RESULTS AND DISCUSSION \\ Characteristics of Research Subjects}

Six participants performed recording with depth Interviews. The characteristics of the participants are presented in table 1.

All participants involved in this study are teenagers who have experienced menstruation

Table 1. characteristics of the participants

\begin{tabular}{lc}
\hline \multicolumn{1}{c}{ Characteristics } & Percentage \\
\hline Age & $2(33,3 \%)$ \\
$14-16$ years & $4(66,7 \%)$ \\
$16-18$ years & \\
\hline Class & $2(33,3 \%)$ \\
$X$ & $1(11,7 \%)$ \\
XI & $3(50 \%)$ \\
XII & \\
\hline Culture & $6(100 \%)$ \\
Javaness & \\
\hline Age of menarche & $4(66,7 \%)$ \\
$10-13$ years & $2(33,3 \%)$ \\
$13-15$ years & \\
\hline Menstrual cycles & $6(100 \%)$ \\
reguler & 0 \\
unreguler & 0 \\
\hline Menstrual problems & \\
Yes & $6(100 \%)$ \\
No & 0 \\
\hline Consuming of drugs/alcohol & \\
Yes & $6(100 \%)$ \\
No & 0 \\
\hline Home-School & \\
$<5$ km & $4(66,7 \%)$ \\
$6-10$ km & 0 \\
$11-15$ km & $2(33,3 \%)$ \\
$16-20$ km & \\
\hline &
\end{tabular}


with regular menstrual cycles (21-35 days) and did not experience menstrual disorders such as premenstrual syndrome, oligomenorrhea, polygomenorrhea, amenorrhea and do not have a history of endometriosis and consumption of certain drugs and alcoholic. All participants are native Javanese and reside in Cangkringan with a distance of 6-10 km by four students and 16-20 $\mathrm{km}$ by two students.

\section{Thematic Analysis}

There are four themes that describe the experiences of adolescents who experience symptoms of Premenstrual Dysphoric Syndrome (PMDD), namely :

Theme 1: Symptoms perceived as a change that affects the psychological, behavioral and physical teens.

Researchers found three categories in this theme namely the symptoms of psychological, behavioral and physical changes.

"... Hmmmm .... that's what ..... before it .... difficult to concentrate, then sometimes likes to be angry, then suddenly cry, sad .........stomach ache, often feel like it .. "

Participants said that psychological symptoms such as difficulty to concentrate, suddenly crying, sad, resentful, irritable, sensitive and anxious. Behavior Symptoms such as often be angry, daydreaming, appetite changes (decreases or increases), decreased interest in activities or lazy, nasty, stingy, bad and loud speaking, bad talking, violent behavior, sleep disorders and fierce. One participant phrase like this:

"... No .... last night at home many noisy all .... I .... abc (bad talking)... then it .... then.... Mom, I really dislike this condition at home!"
Changes in perceived physical symptoms of participants among others; tiredness, abdominal pain, back pain, such as colds, cold feet, feeling feverish, breast tenderness, a face looked pale, pain in the vagina and stomach such as gastritis.

\section{Theme 2: Symptoms of intermittent throughout the menstrual cycle.}

Participants said the symptoms felt by a few days before menstruation and continued for several days in a menstrual period. Two participants said if they felt the Sadness symptoms and suddenly cried when going to sleep, cry at night until go to sleep.

\section{"Sometimes if the night was suddenly crying, ... hmm usually sad Just going to bed keeps crying fit to.. then not know how long .... then fell asleep .. wake up already big eyes ....."}

Difficult to concentrate felt of all participants often occur at school during the day right after the second rest period ie 12 o'clock to finish school hours. Five participants felt abdominal pain often occurs on day 1-3 of menstruation.

\section{Theme 3: Environmental factors and hormones play a role in the emergence of symptoms.}

Factors causing symptoms namely external factors are derived from the surrounding environment and internal factors derived from the individual hormonal. External factors presented participants, among others; many activities at school, do not like what your friends, annoyed with waffle friend, angry because the class atmosphere is noisy, restless sleep for fear of menstrual blood through to clothing, crying because of the friend, friend problems and personal issues. The Symptoms from Internal factors is influenced by hormonal changes that have no known cause. 
"Hmm .... how ...... if I look someone like friends, I just dislike it ...whatever he or she doing in front of me, I dislike all..."

\section{Theme 4: The symptoms cause discomfort and interfere with social relationships teenagers}

Researchers found three categories in this theme namely discomfort and debilitating, disrupt relationships with friends, and strained relations with family.

The inconvenience caused due to the influence of physical symptoms such as stomach pain and breast feels tight. While psychological symptoms such as difficulty concentrating impact on learning disorders, especially when in school, such as the following participant statement:

"Not comfortable at all .., .. disrupt concentration for learning also how school was so shattered"

Symptoms of changes in behavior such as tantrums with close friends, classmates, the same mother and sister have an impact on relationships with friends and family.

\section{DISCUSSIONS}

Affective and somatic symptoms that are experienced by the adolescences mainly happen in two to three days before menstruation until the second day of the menstrual period. This shows that the symptoms occur at the luteal phase of the menstrual cycle. In the luteal phase changes of serotonin function in the central nervous system(12). Estrogen is an important substance that stimulates serotonin receptors. Then affect the regulation of emotions, behavior and cognitive function. Therefore, it is possible that estrogen may play a role in the development of the symptoms of PMS/ PMDD(13).
The onset of symptoms is derived from a variety of stressors are perceived adolescent life(14). Stressors experienced by everyday can improve the symptoms of PMDD in women and the experience of stress was found to have a high percentage in the incidence of PMS and $\operatorname{PMDD}(15)$.

Most teens say do not know what caused the PMDD symptoms they feel. They say such a feeling sad and cry that suddenly appear or come without reason. This is an internal factor caused due to hormonal influences in the luteal phase. The inconvenience in theory Audrey Gift, a collection of perceived symptoms indicate a change in the normal function of the subjectively as an indicator of the health threat. Factors that influence the discomfort is a factor physiological, psychological, and environment where each other are interrelated and have a reciprocal relationship(16). Adolescent discomfort arises due to somatic symptoms or physical symptoms such as abdominal pain, tight breasts, fatigue, and affective symptoms such as difficulty concentrating and so forth.

The inconvenience interferes with daily activities teens, especially learning their main task as a student. It is natural to happen because of the perceived PMDD symptoms cause discomfort in adolescents. Somatic symptoms such as abdominal pain, breast tight and others will influence the affective symptoms such as irritability, irritability, and others, and vice versa. Teens convey that the stomach ache, the more her irritability and difficulty concentrating, and vice versa. Feeling of discomfort that causes adolescents learning difficulties both at school and at home for learning to require a comfortable environment and peace of mind. Besides disturbing activities, affective symptoms such as angry, irritable, and so also disrupt social relationships with friends and family (17). 
The process of social relationships will occur when there are two people or more social contact and communication. Terms of social interaction that is the contact and communication(18). Adolescents say to be less familiar with his close friend when feeling the symptoms and when at home, adolescents prefer to remain silent in the room alone than to gather with other family members. This will certainly reduce the contact and communication between friends and family.

\section{CONCLUSION AND RECOMMENDATION}

Adolescences' experience of having the symptoms of Premenstrual Dysphoric Disorder (PMDD) can be described in four themes. The said themes include 1) Symptoms perceived as a change that affects the psychological, behavioral and physical teens. 2) Symptoms of intermittent throughout the menstrual cycle, 3) Environmental factors and hormones play a role in the emergence of symptoms. and 4) symptoms cause distress and interfere with social relationships adolescents.

Experience adolescents who experience symptoms of post-disaster PMDD are substantially the same as the normal condition in which the cause of discomfort that interferes adolescent social relations. Nurses and other health Services are expected to more actively participate to provide a wide range of related reproductive health education.

\section{REFERENCES}

1. Abeer Eswi, Helal $\mathrm{H}$, Elarousy and W. Menstrual Attitude and Knowledge among Egyptian Female Adolescents. 2012;8(6):55565.

2. Bertone-johnson ER, Whitcomb BW, Richedwards JW, Hankinson SE, Manson JE. Original Contribution Premenstrual Syndrome and Subsequent Risk of Hypertension in a Prospective Study. 2015;182(12):1000-9.
3. Hapsari, Elsi Dwi; Mantani, Yuria; Matsuo H. The Prevalence of Premensrual Dysphoric Disorder and Its Modulation by Lifestyle and Psychological Factors in High School Students.

4. Braverman PK. Premenstrual Syndrome and Premenstrual Dysphoric Disorder. 2007;312.

5. Dennerstein L, Lehert P, Heinemann K. Global study of women's experiences of premenstrual symptoms and their effects on daily life. 2011;17(3):88-95.

6. Seedat S. Post-traumatic stress disorder. 2013;19(3):187-91.

7. Morrissey SA, Reser JP. Original Article Natural disasters , climate change and mental health considerations for rural Australia. 2007;120-5.

8. Rahmadian; Ali A. Prevalensi PSTD dan Karakeristik Gejala Stres Pascatrauma pada Anak dan Remaja Korban Bencana Alam. :1-17.

9. Delara M, Ghofranipour F, Azadfallah P, Tavafian SS, Kazemnejad A. Health related quality of life among adolescents with premenstrual disorders : a cross sectional study. 2012;1-5.

10. Biggs WS, Academy A, Demuth $\mathrm{KRH}$, State M, Lansing E. Premenstrual Syndrome and Premenstrual Dysphoric Disorder. 2011;

11. Lundman B, Norberg A. Women's perceptions of phenomena they label premenstrual tension : normal experiences reflecting ordinary behaviour. 1999;30(4):916-25.

12. Hand $\mathrm{H}$. The ups and downs of the menstrual cycle. 2010;21(9).

13. Bahamondes L, Santiago C. Perspectives on Premenstrual Syndrome / Premenstrual Dysphoric Disorder. 2007;15(5):263-77.

14. $\mathrm{Rn} B L, \mathrm{Rn}$ AN. Whose voice? Whose experiences? Women's qualitative accounts of general and private discussion of premenstrual syndrome. 2002;(3). 
15. Kadian S, Brien SO. Classification of premenstrual disorders as proposed by the International Society for Premenstrual Disorders. 2012;43-7.

16. Abdelmoty HI, Youssef MA, Abdel-malak K, Hashish NM, Samir D, Abdelbar M, et al. Menstrual patterns and disorders among secondary school adolescents in Egypt. A cross-sectional survey. BMC Womens Health [Internet]. BMC Women's Health; 2015;1-6. Available from: http://dx.doi.org/10.1186/ s12905-015-0228-8
17.Žukov I, Ptá R, Raboch J, Domluvilová D, Kuželová H. Premenstrual Dysphoric Disorder - Review of Actual Findings about Mental Disorders Related to Menstrual Cycle and Possibilities of their Therapy. 2010;111(1):12-24.

18.Perz, Janette; Ussher JM. Women's experience of premenstrual syndrome : a case of silencing the self. $2006 ; 24(4): 289$ 303. 